\title{
DUAL EDUCATION IN SLOVAKIA UNDER NEW CONDITIONS
}

\author{
Dagmar ZMEKOVÁ, Považská akadémia vzdelávania, n. o., Nové Mesto \\ nad Váhom, Slovenská republika
}

Danka LUKÁČO $\boldsymbol{A}^{*}$, Univerzita Konštantína Filozofa v Nitre, Slovenská republika

Přijato: 12. 2. 2019 / Akceptováno: 11. 6. 2019

Typ článku: Teoretická studie

DOI: $10.5507 /$ jtie.2019.004

Abstract: Dual education is a system of interconnection of vocational theoretical education with the practical preparation of a pupil. It mainly requires cooperation in the preparation of pupils between employers and secondary vocational schools and at the same time requires the interconnection of education with the labor market as it is necessary to reconcile the number of offered teaching and study disciplines with the real needs of employers. In Slovakia, the system of dual education has been gradually introduced since year 2015. In 2018, fundamental changes were made to facilitate the entry of firms into the system of pupil preparation. The article based on the example of the secondary vocational school in Stará Turá analyzes the changes made in the dual education system and proposes new approaches to the provision of vocational training at the secondary vocational schools in Slovakia, taking into account the experience from other countries.

Key words: dual education, secondary vocational school, firm, example of good practice.

\section{DUÁLNE VZDELÁVANIE NA SLOVENSKU V NOVÝCH PODMIENKACH}

Abstrakt: Duálne vzdelávanie je systém prepojenia odborného teoretického vzdelávania s praktickou prípravou žiaka, pričom je potrebná spolupráca pri príprave žiakov medzi zamestnávatelmi a strednými odbornými školami a zároveň si vyžaduje prepojenie školstva s trhom práce, pretože je potrebné zosúladenie počtu ponúkaných učebných a študijných odborov so skutočnými potrebami zamestnávatelov. Na Slovensku sa postupne zavádza systém duálneho vzdelávania od r. 2015. V roku 2018 prišlo k zásadným zmenám, ktoré majú ul'ahčit' vstup firmám do systému prípravy žiakov. Článok na priklade SOŠ $v$ Starej Turej analyzuje zmeny dosiahnuté v systéme duálneho vzdelávania a navrhuje nové prístupy k zabezpečeniu odborného vzdelávania na SOŠ na Slovensku, pričom berie do úvahy aj skúsenosti z iných krajin.

Klíčová slova: duálne vzdelávanie, stredná odborná škola, firma, príklad dobrej praxe.

*Autor pro korespondenci: dlukacova@ukf.sk 


\section{1 Úvod}

V Dánsku, Nemecku a mnohých d’alších krajinách je odborné vzdelávanie a príprava založené na princípe duálneho vzdelávania. To znamená, že žiaci trávia jednu čast' svojho vzdelávania a odbornej prípravy v odbornej škole a d'alšiu čast' v spoločnosti alebo firme priamo zapojenej do bežného pracovného života. Blízke napojenie na pracovný život znamená l'ahší prechod k tomu, aby sa učiaci stal zamestnancom, čo je jednoduchšie v systéme duálneho vzdelávania v porovnaní s inými systémami odborného vzdelávania a prípravy na školách (Koudahl P., 2010).

V súčasnej dobe sa na Slovensku vyvíja zo strany vlády, ministerstiev, vedenia krajov, miest a obcí iniciatíva smerujúca $\mathrm{k}$ väčšiemu rozvoju systému duálneho vzdelávania. Presadzuje sa úzke prepojenie všeobecného a odborného vzdelávania s praktickou prípravou žiaka u konkrétneho zamestnávatel'a. Dôvodom je vy̌šsia predpokladaná zamestnanost', kvalifikovanost' pracovníkov a vyplnenie pracovného priestoru tam, kde kvalifikované kádre chýbajú. Vel'ký dôraz sa kladie na zamestnávatel'ov a ich iniciatívy a z tohto dôvodu riadiace orgány prispôsobujú a upravujú legislatívu tak, aby vyšli firmám vstupujúcim do duálneho systému v ústrety a skvalitnili praktické vyučovanie.

Na Slovensku sa systém duálneho vzdelávania začal zavádzat' v r. 2015 a v prvom roku sa prihlásilo 130 zamestnávatel'ov, ktorí mali vytvorit' 1800 pracovných miest pre žiakov študujúcich v systéme duálneho vzdelávania. Len 32,5 \% žiakov zareagovalo na ponuky duálneho vzdelávania, ktoré boli reálne ponúknuté zamestnávatel'mi. Bolo vytvorených 1440 pracovných miest, o ktoré malo záujem len 468 žiakov. Nízky záujem sa vysvetl'oval tým, že duálny systém je ešte len v začiatkoch a v d'alších školských rokoch žiaci prejavia ovel'a vyšší záujem. Ďalšou možnou príčinou bol nedostatok času na nábor žiakov.

Počet zamestnávatel'ov, škôl i žiakov vstupujúcich do systému duálneho vzdelávania v šk. roku 2016/2017 sa oproti roku 2015/2016 zdvojnásobil. Uzatvorených bolo 1121 učebných zmlúv a celkovo bolo do systému zapojených 1543 žiakov. Teda celkové výsledky sa podl'a škôl zlepšili, zamestnávatelia sa však st’ažovali na nedostatočný záujem žiakov o prípravu na povolanie. Do duálneho vzdelávania bolo zapojených 142 zamestnávatel'ov, ktorí vytvorili 172 prevádzok, kde prebiehalo praktické vyučovanie. Počet škôl zapojených do duálneho vzdelávania od septembra 2016 bolo 57 a počet učebných oborov 47. Tento počet zapojených firiem a škôl je však stále nepostačujúci, nakol'ko účast' zamestnávatel'ov v systéme duálneho vzdelávania sa predpokladá na úrovni 1450 zamestnávatel'ov, 7 stavovských a profesijných organizácií i 280 stredných odborných škôl (www.skolsky servis.sk).

Nedoriešenou otázkou je aj zastúpenie jednotlivých odvetví priemyslu a služieb v duálnom systéme. Predovšetkým sú v ňom firmy, ktoré reprezentujú strojársky priemysel, ktorých je za sledované obdobie 2017/2018 55 \%. Ďalšie výrazne zastúpenie má elektrotechnický priemysel, čo predstavuje $29 \%$. Elektrotechnický priemysel je úzko spätý s automobilovým priemyslom, preto má také dôležité zastúpenie v ponuke učebných miest. Ostatné oblasti vysoko zaostávajú za vyššie vymenovanými oblast’ami priemyslu: oblast' hospodárstva a služieb $-8 \%$, stavebníctvo $-5 \%$ a ostatné trhové segmenty na úrovni $3 \%$. (www.novydualnysystem.sk)

Toto zistenie považujeme za vel'mi problematické z dôvodu, že na jednej strane tento trend kopíruje požiadavky trhu práce, no na druhej strane sa netreba zameriavat' len na strojárstvo a automobilový priemysel, ale je potrebné vytvorit' vhodné podmienky na 
diverzifikáciu hospodárstva aj na udržatel'né, či ostatné segmenty. Dôležité je podporovat' služby, pol'nohospodárstvo, životné prostredie, cestový ruch a pod.

Udržat' funkčný systém odborného duálneho vzdelávania vyžaduje zabezpečit' angažovanost' podnikov, ich dostatočný počet s dobrou kvalitou vzdelávania. $\mathrm{K}$ tomu je potrebné zjednodušenie procesu certifikácie podniku pre systém duálneho vzdelávania, lepšie stimuly pre zamestnávatel’ov, možnosti vytvorenia spoločného pracoviska praktického vyučovania, normatívne financovanie škôl a d’alšie faktory, ktoré od 1.9.2018 rieši nový Zákon 209 zo dňa 14. júna 2018, ktorým sa mení a dopíña Zákon č. 61/2015 Z. z. o odbornom vzdelávaní a príprave.

Vel’mi dôležitými zmenami sú benefity zamestnávatel’a, kde sa na základe učebnej zmluvy znižuje základ dane, poskytuje príspevok na zabezpečenie praktického vyučovania a uplatňovanie daňových výdavkov. Doterajšie štúdie a analýzy poukazujú na to, že odborné vzdelávanie zabezpečuje podnikom kvalifikovaných zamestnancov, čím si podporujú prevádzkovú kontinuitu. Vychovanými a vyškolenými pracovníkmi môžu lepšie a rýchlejšie zabezpečovat' inovácie, či už v oblasti nových technológií alebo vo vyššej kvalite výrobkov. Úžitok v rámci vzdelávania je podstatným určujúcim faktorom pre vzdelávacie ponuky zo strany podnikov, ktorý sa však pri zosumarizovaní všetkých benefitov nedá vyjadrit' výlučne iba produktívnou prácou. Pri vstupe firmy do systému duálneho vzdelávania sa zamestnávatel’ovi výrazne skracuje doba dosiahnutia výkonu a efektivity práce absolventa školy na úroveň výkonu a efektivity práce zamestnancov s niekol'koročnou praxou. Pre žiaka je dôležité, že si osvojuje pracovné návyky priamo vo výrobnom procese u zamestnávatel'a, na jeho technologických zariadeniach a učí sa byt' úzko spätý s pracovným prostredím a pracovným kolektívom. $Z$ tohto vyplýva vel'mi vel'ká pravdepodobnost' získania pracovnej zmluvy so zamestnávatel'om. Pokial' nevznikne medzi vyučeným žiakom a vzdelávacím podnikom $\mathrm{z}$ nejakej príčiny zamestnanecký pomer, môžu prejst' vyučení, kvalifikovaní pracovníci do iných podnikov. Aj takáto „fluktuácia“ je možná pri slobodnom vzdelávacom systéme. Toto si uvedomujú aj vel'ké podniky, ktoré investujú do vzdelávania, že pôsobia v prospech všetkých príbuzných hospodárskych a profesijných odvetví, ktoré potrebujú kvalifikovaných, odborne vzdelaných absolventov. Sami to tiež využívajú a pre svoje potreby si zabezpečujú aj pracovné sily vyučené mimo podnik.

\section{Použité metódy}

V d’alších častiach príspevku sme použili teoretické metódy pedagogického výskumu, najmä literárnu metódu. Extrahovali sme a v nových súvislostiach spracovali informácie z interných materiálov poskytnutých SOŠ v Starej Turej. Išlo o učebné zmluvy medzi školou a zamestnávatel'mi a učebné plány jednotlivých študijných odborov. Pri vyhodnocovaní informácií sme sledovali počty firiem, s ktorými má škola uzavreté zmluvy, počty žiakov zapojených do duálneho systému vzdelávania prípravy, rozsah a organizáciu praktického vyučovania a jeho personálne zabezpečenie majstrami odbornej výchovy a inštruktormi. Túto školu sme vybrali zámerne, nakol'ko sa do systému duálneho vzdelávania zapojila už v r. 2015, s ciel’om zistit', ako v súčasnosti realizuje duálne vzdelávanie, kol'ko firiem spolupracuje so školou, kol'ko žiakov a kol'ko študijných odborov je do systému zapojených. 


\section{Duálne vzdelávanie na SOŠ Stará Turá}

Stredná odborná škola (SOŠ) Stará Turá začala so zavádzaním systému duálneho vzdelávania v roku 2015. Začiatky boli komplikované z dôvodu vtedajšej legislatívy, podniky neboli dostatočne informované a pripravené na prijatie žiakov. Jednanie s firmami prebiehalo vel'mi pomaly a informovanost' žiakov a rodičov viazla. I ked' niektoré firmy spolu so školami pripravovali informačné letáky, ktoré vysvetl'ovali výhody systému duálneho štúdia, vel'ká prekážka sa javila pri agitácii rodičov. Postupne sa však podarilo spolu s firmami začat' odborné vzdelávanie v systéme duálneho vzdelávania a zdá sa, že počiatočné ,pionierske“ kroky boli prekonané a duálne vzdelávanie sa rozbehlo.

Dnes škola spolupracuje a má uzavreté zmluvy o duálnom vzdelávaní s firmami:

CHIRANA T Injecta, EX METAL, Chirana Medical \& Dental Company a Honeywell of connected. Dve firmy Chirana vyrábajú zdravotnícku techniku a to Injecta - injekčnú techniku a Medical \& Dental Company dentálnu a narkotizačnú techniku. Obe firmy sú dlhodobým tradičným výrobcom a ich produkcia ide z $80-90 \%$ na export. Chirana Medical \& Dental Company má svoje výrobky ocenené a získala v priebehu 10 rokov trikrát národnú cenu SR za dizajn so svojimi stomatologickými súpravami a kreslami. Ďalšie dve firmy sú so zahraničnou účast'ou, spadajú pod organizáciu nadnárodných firiem a majú vel'ký záujem o úspešný priebeh duálneho štúdia.

Škola má zatial' v systéme duálneho štúdia zapojené tri ročníky:

1. ročník:

Mechanik elektrotechnik

10 žiakov

Mechanik nastavovač

11 žiakov

Mechanik počítačových sietí

18 žiakov

2. ročník:

Mechanik elektrotechnik

8 žiakov

Mechanik nastavovač

12 žiakov

Mechanik počitačových sietí

16 žiakov

3. ročník:

Mechanik nastavovač

20 žiakov

Mechanik elektrotechnik

10 žiakov

Mechanik počitačových sietí

10 žiakov

Pre každý študijný odbor je vypracovaný učebný plán a učebné osnovy, ktoré zodpovedajú vzorovým učebným plánom podla vtedajšej legislatívy Zákona 61/2015 Z.z. Od 1.9.2018 sa však žiak môže $\mathrm{v}$ systéme duálneho vzdelávania vzdelávat' podla školského vzdelávacieho programu spracovaného podl'a rámcového učebného plánu aktuálneho štátneho vzdelávacieho programu. Vzorové učebné plány budú mat' od 1.9.2019 len odporúčací charakter.

Žiaci prvého ročníka vykonávajú praktické vyučovanie na pracovisku praktického vyučovania $\mathrm{v}$ škole a takto sú spracované aj pracovné zmluvy o duálnom vzdelávaní so zamestnávatel’om, kde sú dohodnuté všetky náležitosti zabezpečenia praktického vyučovania vrátane finančného. $V$ d’alších ročníkoch sa praktické vyučovanie vykonáva v priestoroch zamestnávatel'a podl'a platnej legislatívy zákona 61/2015 Z. z. a od 1.8.2018 aj podla novelizácie Zákona 61/2015 Z.z. - podl’a Zákona 209 zo 14. júna 2018. V prvom ročníku sa teda praktické vyučovanie vykonáva $\mathrm{v}$ priestoroch školy, kde sú žiaci vedení učitel'mi odbornej výchovy. Počet učitel'ov odbornej výchovy je šest', rozdelení sú podl'a profesie. Všetci učitelia odbornej výchovy majú ukončený I. stupeň vysokoškolského vzdelania (Bc.) 
V d’alších ročníkoch praktické vyučovanie prebieha v priestoroch zamestnávatel'ov, kde sú žiaci vzdelávaní, kontrolovaní a vedení inštruktormi. Inštruktori sú určení vždy pre vybraný ročník a profesiu. Vzdelanie inštruktorov u zamestnávatel'ov je stredoškolské $\mathrm{s}$ maturitou, výučný list a kurz pre inštruktorov duálneho vzdelávania v závislosti od toho, na akej pozícii je inštruktor zaradený. Systém duálneho vzdelávania rozlišuje hlavného inštruktora, ktorý komplexne zabezpečuje odborné vzdelávanie a prípravu žiakov (najviac troch) na pracovisku praktického vyučovania a povereného inštruktora, ktorý vedie žiakov (najviac troch) v rámci praktického vyučovania v rozsahu výrobnej činnosti, ktorá zodpovedá jeho pracovnému zaradeniu. Každé pracovisko praktického vyučovania musí mat' určeného aspoň jedného hlavného inštruktora a primeraný počet poverených inštruktorov podla počtu žiakov.

Príprava hlavných inštruktorov obsahuje v rámci kurzu tri moduly: praktické vyučovanie u zamestnávatel'a, plánovanie a organizácia praktického vyučovania, realizácia práce so žiakom na praktickom vyučovaní v rozsahu 24 hodín prezenčnej výučby a 16 hodín dištančného vzdelávania. Poverení inštruktori absolvujú vzdelávanie rovnakých vzdelávacích modulov, ale v omnoho menšom rozsahu - iba 8 hodín. Lektori, ktorí vzdelávajú inštruktorov, musia mat' prax v lektorskej, pedagogickej alebo riadiacej činnosti, primeranú odbornost' $\mathrm{v}$ danom odbore a na vzdelávanie ich môže nominovat' stavovská alebo profesijná organizácia, združenie zamestnávatel'ov, komora, cech alebo zamestnávatel' so systémom duálneho vzdelávania, ktorý má viac ako 20 inštruktorov (Kováč, L., 2016). Právo organizovat' kurzy pre inštruktorov duálneho vzdelávania majú iba príslušné stavovské organizácie, profesijné organizácie a v rámci národného projektu Duálne vzdelávanie a zvýšenie atraktivity a kvality OVP aj Štátny inštitút odborného vzdelávania.

V zmluve o duálnom vzdelávaní medzi SOŠ Stará Turá a zamestnávatel’om je uvedený počet a zoznam inštruktorov, pod vedením ktorých budú žiaci vykonávat' praktické vyučovanie u zamestnávatela. Klasifikáciu prospechu žiaka, ktorý vykonáva praktické vyučovanie pod vedením inštruktora, realizuje na základe podkladov a d’alších informácií od inštruktora pedagogický zamestnanec školy. Pre spoluprácu so školou má škola určeného pedagogického pracovníka, ktorý koordinuje, klasifikuje a vykonáva kontroly a úzko spolupracuje s inštruktormi v jednotlivých firmách.

Rozsah praktického vyučovania vyjadrený celkovým počtom vyučovacích hodín praktického vyučovania vo forme odborného výcviku podl'a učebného plánu školského vzdelávacieho programu je zhrnutý v tabul'ke 1 .

Praktické vyučovanie zamestnávatel' žiakovi poskytuje podl’a rozvrhu vyučovacích hodín spracovaného školou v spolupráci so zamestnávatel’om. Rozvrh vyučovacích hodín obsahuje zaradenie a poradie vyučovacích predmetov na jednotlivé vyučovacie dni v kalendárnom týždni. Rozvrh vyučovacích hodín je rozpísaný na párny a nepárny kalendárny týždeň samostatne. Harmonogram striedania dní teoretického vyučovania a praktického vyučovania je uvedený $\mathrm{v}$ školskom vzdelávacom programe alebo v pláne výchovno-vzdelávacej činnosti školy na príslušný školský rok. 


\begin{tabular}{|c|c|}
\hline ročník & $\begin{array}{l}\text { počet vyučovacích hodín praktického vyučovania vo forme } \\
\text { odborného výcviku* }\end{array}$ \\
\hline 1. ročník & $495 \mathrm{~h}$ \\
\hline 2. ročník & $577,5 \mathrm{~h}$ \\
\hline 3. ročník & $577,5 \mathrm{~h}$ \\
\hline 4. ročník & $525 \mathrm{~h}$ \\
\hline
\end{tabular}

\section{Tab. č. 1: Rozsah praktického vyučovania v jednotlivých ročníkoch.}

Organizácia praktického vyučovania, začiatok a koniec vyučovacieho dňa praktického vyučovania a prestávky žiakov počas vyučovacieho dňa sú určené zamestnávatel'om vo vnútornom poriadku pracoviska praktického vyučovania $v$ súlade s vyhláškou č. 65/2015 Z. z. o stredných školách $\mathrm{v}$ znení neskorších predpisov. Zamestnávatel' preukázatel'ne oboznamuje žiaka s vnútorným poriadkom pracoviska praktického vyučovania, poskytuje žiakovi na svoje náklady hmotné a finančné zabezpečenie žiaka.

O takto nastavený systém duálneho vzdelávania prejavujú žiaci záujem, aj ked’ je potrebné stále pracovat' na komunikácii najmä s rodičmi uchádzačov o štúdium. Žiaci, ktorí toto vzdelávanie absolvujú, sú na prax dobre pripravení, avšak objavuje sa nový fenomén - niektorí žiaci po získaní základných zručností neukončia svoje vzdelávanie a odchádzajú zo školy pracovat'. Súvisí to určite aj s tým, že v súčasnosti je v praxi dopyt po zručných pracovníkoch a preto nemajú problém získat' prácu. Preto bude potrebné neustále monitorovat' výsledky systému duálneho vzdelávania a po skončení prvých absolventov (v tomto školskom roku) uskutočnit SWOT analýzu. Čas a postoje zúčastnených strán $\mathrm{v}$ budúcnosti ukážu, aké budú cesty a výsledky duálneho vzdelávania. Dôkazom môže byt' aj minulost', nakol'ko do roku 1989 existovalo prepojenie praktického vzdelávania $v$ školách a podnikoch po celé desatročia. Nie je to nič nové, len duálne vzdelávanie sa musí prispôsobit' novým podmienkam súčasnosti.

\section{Diskusia a záver}

$\mathrm{Na}$ základe doterajších skúseností s implementáciou duálneho systému vzdelávania môžeme vyslovit' niekol'ko odporúčaní na jeho zlepšenie:

- Posunút' začiatok praktickej výučby $\mathrm{v}$ trojročných učebných a študijných odboroch do 2. ročníka a v štvorročných odboroch do 3 . ročníka.

- Modernizovat' vybavenie SOŠ tak, aby reflektovalo požiadavky firiem.

- Zniźit minimálny počet žiakov $\mathrm{v}$ triedach $\mathrm{s}$ duálnym vzdelávaním, čo by umožnilo zaviest' tento systém aj v odboroch, o ktoré nie je až taký záujem.

Zatial' všetky výsledky odborného vzdelávania realizované s uplatnením princípov duálneho vzdelávania na Slovensku hovoria $\mathrm{v}$ jeho prospech. Je však potrebné poučit' sa $\mathrm{z}$ jeho realizácie $\mathrm{v}$ iných krajinách, ktoré ho využívajú už dlhšiu dobu a upozorňujú aj na možné negatívne stránky zapojenia firiem do odbornej prípravy žiakov.

V dôsledku hospodárskej krízy $\mathrm{v}$ roku $2008 \mathrm{v}$ Európe počet miest vo firmách zapojených do duálneho systému z pochopitel’ných dôvodov klesol a stúpol počet mladých l'udí, ktorí nevideli budúcnost' v stredoškolskom odbornom vzdelaní (Koudahl P., 2006, 2008). Inými slovami, princíp duálneho vzdelávania je pod tlakom trhu - rovnako ako $\mathrm{v}$ iných krajinách, ktoré organizovali svoje systémy odborného vzdelávania a prípravy 
žiakov podla princípov duálneho vzdelávania a spolupráca s firmami je závislá od ich ekonomických pomerov.

Výsledky odbornej prípravy z Holandska a Rakúska naznačujú, že je potrebné, aby na trhu práce bolo akceptované, že všetky kombinácie - podnikové, vzdelávacie a školské systémy odborného vzdelávania a prípravy - sú rovnako dobré a kvalitné kvalifikačné systémy pre odbornú prípravu žiakov.

$\mathrm{Na}$ druhej strane by sme mohli otázku tréningových miest ponechat' úplne na trhu práce. To by zabezpečilo zhodu medzi počtom žiakov a počtom tréningových miest vo firmách. Mohlo by sa však stat', že by nebol zabezpečený dostatočný počet tréningových miest pre všetkých žiakov, ktorí chcú absolvovat' duálne vzdelávanie a existuje riziko, že sa systém odborného vzdelávania bude rozvíjat' smerom $\mathrm{k}$ modelu trhu, čo by z dlhodobého hl'adiska nebolo pre spoločnost' výhodné.

Článok je výsledkom riešenia projektu KEGA 011UKF-4/2017.

\section{Literatura}

Koudahl, P. (2006). Den gode erhvervsuddannelse. Analyse af relationerne mellem uddannelsespolitisk toenkning og elever i erhvervsuddannelse. Ph.d.dissertation. Roskilde University. Department of Educational Research.

Koudahl, P. (2008). Et feltanalystisk blik på de danske erhvervsuddannelser - med eksempler fra uddannelsespolitiske strømninger. Cursiv No.3/2008. Danish School of Education, Department of Curriculum Research. Aarhus University.

Koudahl, P. (2010). Vocational education and training: dual education and economic Crises. In Procedia Social and Behavioral Sciences 9, 2010, p. 1900-1905.

Kováč, L. (2016). Zabezpečenie prípravy inštruktorov pre praktické vyučovanie u zamestnávatel'a na pracovisku praktického vyučovania. Metodický pokyn MP-02-2016. Rada zamestnávatel'ov pre systém duálneho vzdelávania, 2016, $14 \mathrm{~s}$.

Do duálneho vzdelávania by sa malo do roku 2020 zapojit' 12.000 žiakov. Dostupné na internete: http://skolskyservis.teraz.sk/skolstvo/system-dualneho-vzdelavania-svit/31072clanok.html

Učebný plán študijného odboru Mechanik elektrotechnik. SOŠ Stará Turá. Interné materiály.

Učebný plán študijného odboru Mechanik nastavovač. SOŠ Stará Turá. Interné materiály. Učebný plán študijného odboru Mechanik počítačových sietí. SOŠ Stará Turá. Interné materiály.

Zákon č. 61/2015 Z. z. Zákon o odbornom vzdelávaní a príprave a o zmene a doplnení niektorých zákonov.

Zákon č. 209/2018 Z.z., ktorým sa mení a doplña zákon č. 61/2015 Z. z. o odbornom vzdelávani a priprave a o zmene a doplneni niektorých zákonov a ktorým sa menia a doplñajú niektoré zákony.

Zmeková, D. \& Hargaš, J. (2018). Dual education in Slovakia - the weaknesses and the threats of the dual system. In R\&E-SOURCE, online Journal for Research and Education, Special Issue 13, Dec. 2018, p. 168-171. Dostupné na internete: https://journal.ph-noe.ac.at Komplexná záverečná správa o činnosti za rok 2018. Dostupné na internete:

http://novy.dualnysystem.sk/wp-content/uploads/2019/04/Sprava-za-rok-2018-A3.pdf 